\title{
Kajian Tipologi Pesisir Di Muara Sungai Pemali Kabupaten Brebes Provinsi Jawa Tengah
}

\author{
Eko Ali Saputro, Totok Gunawan, Slamet Suprayogi
}

Masuk: 24022021 / Diterima: 05032021 / Dipublikasi: 30062021

\begin{abstract}
The occurrence of abrasion and accretion in the Pemali River indicates that the coast of Brebes Regency be highly dynamic, where land use becomes more complex related to the dynamics of coastal change. Activities in the oceans and land within a certain period will form different coasts depending on genetic processes and constituent materials. Each coastal typology will characterize the landscape and various kinds of resources that exist in the coastal area. The management and utilization of resources will differ according to the typology of the developing coastal area. This study aims to determine the typology of coastal areas, analyze potential and problems, and formulate alternative solutions to the problems in the Pemali River Mouth, Brebes Regency. The method used in this study is descriptive analysis, descriptivequantitative, descriptive-comparative and correlative analysis methods. The results showed that overall the physical typology of the coastal area in the study area is ocean and land deposition of the coastal area. The typology has potential and problems; therefore, the management alternatives are formulated based on the problems. The alternative management formulation includes rehabilitating mangroves, building coastal protection structures, making regional regulations regarding coastal committees, conducting an inventory of land ownership, determining protected and conservation areas, and carrying out comprehensive land management in coastal areas.
\end{abstract}

Keywords: Coastal Typology; Management Coastal Area; Estuary

\begin{abstract}
Abstrak Terjadinya Abrasi dan Akresi di Muara Sungai Pemali Menandakan Pesisir Kabupaten Brebes sangat dinamis, Dimana penggunaan lahan menjadi sangat kompleks terkait dengan dinamika perubahan pesisir. Aktivitas di daratan dan lautan yang berlangsung dalam jangka waktu tertentu akan membentuk jenis pesisir yang berbeda-beda tergantung pada proses genetik dan material penyusunnya. Sehingga tiap tipologi pesisir akan memberikan ciri-ciri pada bentanglahan dan berbagai macam sumberdaya yang ada di wilayah pesisir tersebut. Bentuk pengelolaan dan pemanfaatannya pun akan berbeda disesuaikan dengan bentuk tipologi wilayah kepesisiran yang berkembang. Penelitian ini bertujuan untuk mengetahui tipologi wilayah pesisir, menganalisis potensi dan permasalahan hingga merumuskan alternatif pemecahan permasalahan di Muara Sungai Pemali Kabupaten Brebes. Metode yang digunakan dalam penelitian ini adalah metode analisis deskriptif, deskriptif-kuantitatif, deskriptif-komparatif dan metode analisis korelatif. Hasil penelitian menunjukkan bahwa secara keseluruhan tipologi fisik pesisir daerah penelitian merupakan area pesisir pengendapan laut dan pesisir pengendapan darat. Tipologi yang terbentuk memiliki potensi dan permasalahan sehingga dirumuskan alternatif pengelolaan berdasarkan permasalahan. Rumusan alternatif pengelolaannya antara lain melakukan rehabilitasi Mangrove, membangun struktur pelindung pantai, membuat peraturan daerah tentang sepadan pantai, melakukan inventarisasi kepemilikan lahan, penetapan kawasan lindung dan konservasi, serta melakukan pengelolaan lahan secara menyeluruh di wilayah pesisir pantai.
\end{abstract}

Kata Kunci: Tipologi Pesisir; Pengelolaan Wilayah Pesisir; Muara Sungai

This is an open access article under the CC BY-SA license.

Copyright $(2021$ by Author. Published by Universitas Pendidikan Ganesha.

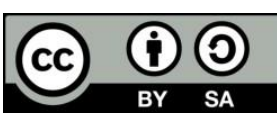




\section{Pendahuluan}

Perubahan terhadap lingkungan dapat terjadi dimanapun baik secara alamiah (faktor alam) maupun secara buatan (faktor manusia). Namun sejalan dengan pertumbuhan penduduk dan kemajuan teknologi, perubahan lingkungan menjurus kedegradasi lingkungan yang dapat menimbulkan bencana alam. Sebagai negara kepulauan terbesar di dunia, Indonesia selain memiliki kekayaan sumber daya alam pesisir yang melimpah, juga memiliki potensi bencana alam yang sangat tinggi (Dahuri et al., 1996; Ruswandi et al., 2008) Kawasan pesisir khususnya wilayah Kabupaten Brebes merupakan wilayah yang sangat dinamis dan memiliki permasalahan yang sangat kompleks, sebab dipengaruhi baik faktor dari alam seperti sedimentasi pantai, erosi pantai dan kenaikan muka air laut, sedangkan faktor manusia manusia seperti, reklamasi (pengurungan pantai), perlindungan pantai (shore protection), penggundulan dan penanaman hutan pantai, pengaturan pola aliran sungai (Ongkosongo, 1982).

Pesisir Kabupaten Brebes tidak terkecuali kondisinya sangat dinamis, dimana penggunaan lahan menjadi sangat kompleks terkait dengan dinamika perubahan pesisir. Kerusakan lingkungan wilayah pesisir dapat disebabkan oleh adanya perencanaan dan pengelolaan sumber daya alam yang tidak seimbang, seperti semakin berkurangnya hutan mangrove sebagai akibat bertambahnya lahan pertambakan di pesisir pantai.

Eko Ali Saputro, Totok Gunawan, Slamet Suprayog Universitas Gadjah Mada, Indonesia

ekoalisaputra@gmail.com
Jenis kerusakan lingkungan yang terjadi di pesisir Kabupaten Brebes adalah abrasi dan akresi dimana menyebabkan kerusakan pada tambak milik warga sekitar. Berdasarkan data dari BAPPEDA Provinsi Jawa Tengah tahun 2005, abrasi terbesar terjadi di Desa Kaliwlingi sebesar $200 \mathrm{Ha}$, Desa Randusanga Kulon sebesar $125 \mathrm{Ha}$, dan Desa Sawojajar 125 Ha. Selain abrasi di beberapa kawasan muncul juga tanah timbul akibat penumpukan material sedimen aktifitas muara sungai pemali. Munculnya tanah timbul sering menjadi sumber konflik dan sengketa warga masyarakat pesisir Kabupaten Brebes.

Aktifitas yang berlangsung di lautan dan di daratan dalam jangka waktu tertentu akan membentuk jenis pesisir (tipologi pesisir) yang berbeda beda tergantung pada proses genetik dan material penyusunnya, sehingga tiap tipologi pesisir akan memberikan ciri-ciri pada bentanglahan dan berbagai macam sumberdaya yang ada di wilayah pesisir tersebut, Maka bentuk pengelolaan dan pemanfaatannyapun akan berbeda disesuaikan dengan bentuk tipologi wilayah kepesisiran yang berkembang (Khakhim, 2009)

Penelitian sebelumnya telah mengkaji beberapa permasalahan yang ada muara Sungai Pemali dan sekitarnya seperti pencemaran kawasan mangrove (Gemilang \& Loka, 2017), dinamika pesisir dan perubahan garis pantai (Prijantono et al., 2009) serta sedimentasi yang terjadi di perairan Kabupaten Brebes (Gemilang et al., 2017) namum belum ada yang melakukan penelitian mengenai tipologi pesisir di muara sungai pemali secara spasial berdasarkan kondisi fisik wilayah pesisirnya. 
Penelitian mengenai tipologi pesisir telah di lakukan di beberapa wilayah seperti Pesisir Kars Gunungkidul (Marfai et al., 2013), Pesisir Demak Eni (Yuniastuti, 2016), dan Pesisir Kawasan Karst Kabupaten Wonogiri (Cahyadi et al., 2017) namun setiap wilayah pesisir memiliki karakteristik yang berbeda dengan wilayah lainnya serta kebijakan pemerintah dalam mengelola kawasan pesisir akan berbeda pula. maka dari itu, identifikasi karakteristik wilayah kepesisiran sangat penting untuk menentukan strategi pengelolaan kawasan pesisir yang berkelanjutan agar sumberdaya pesisir dapat digunakan sekarang dan masa akan datang sehingga sangat diperlukan pengelolaan sumberdaya secara terpadu dan terintegrasi, yang harus didahului dengan beberapa kajian keilmuan antara lain kajian tentang tipologi dan dinamika Pesisir di Kabupaten Brebes (Marfai et al., 2013).

Sehingga hasil penelitian ini diharapkan dapat memberikan referensi tambahan serta masukan bagi pemerintah dalam membuat kebijakan tentang pola pengembangan dan pengelolaan melalui pendekatan analisis tipologi fisik pesisirnya di Kabupaten Brebes khususnya di muara Sungai Pemali. Tujuan dalam penelitian ini yaitu untuk mengkaji Tipologi yang berkembang di wilayah pesisir dan selanjutnya menganalisis potensi serta permasalahan Pesisir di muara Sungai Pemali dan sekitarnya.

\section{Metode}

Penelitian ini dilakukan di wilayah pesisir Kabupaten Brebes, lebih terfokus pada wilayah muara Sungai Pemali dan sekitarnya. Secara Administratif, wilayah pesisir mencakup Kecamatan Brebes dan Kecamatan wanasari meliputi beberapa desa diantaranya Desa Randusanga kulon, Desa Randusanga Wetan, Desa Kaliwingi, dan Desa Sawojajar.

Alat yang digunakan dalam penelitian ini yaitu perangkat komputer berbasis windows lengkap dengan applikasi seperti Microsoft Office, ArcMAP 10.6, Global Mapper 19. Bahan yang digunakan dalam penelitian ini yaitu Peta RBI skala Citra Tegak Resolusi Tinggi Geo-eye, Peta Rupa Bumi Indonesia skala 1: 25.000, Peta Geologi skala 1 : 100.000, Data Digital Elevation Model, Data Batimetri, dan Data Hidro-oseanografi berupa Pasangsurut, angin, gelombang dan arus.

Metode Pengambilan sampel menggunakan purposive sampling, yaitu penentuan titik sampel mendasarkan pada tujuan penelitian. Kajian tipologi memperhatikan kondisi fisik wilayah pesisir. Kondisi fisik ini mendeskripsikan bentuklahannya yang merupakan cerminan kondisi geologi, geomorfologi, lereng, tanah, hidrologi, penggunaan lahan serta aksesbilitas pada lokasi. Hal ini mengacu pada (Rapid Integrated Survey for Coastal Area) Pedoman Survei Cepat Terintegrasi Wilayah Kepesisiran (Gunawan et al., 2005).

Pengolahan data dilakukan dengan rekapitulasi data, manajemen struktur data, dan pembuatan basis data spasial/non spasial hasil lapangan. Tahap pengolahan dan analisis data ini dilakukan untuk berdasarkan tujuan penelitian. Setelah semua data diolah kemudian dilakukan analisis data. Metode yang digunakan untuk analisis data dalam penelitian ini adalah metode analisis deskriptif, deskriptif-kuantitatif, deskriptif-komparatif dan metode analisis korelatif. 


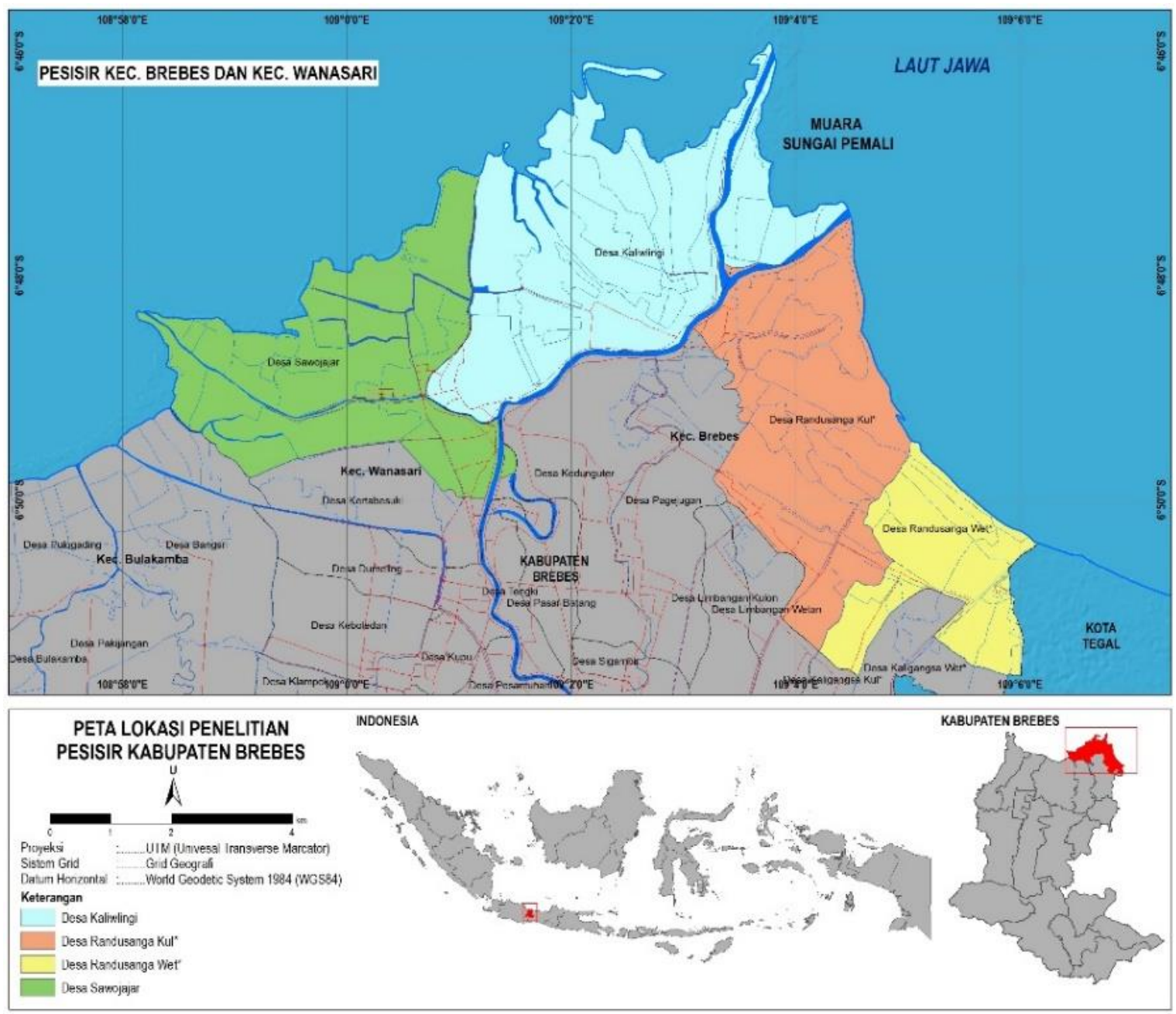

Gambar 1 Peta Lokasi Penelitian

\section{Hasil dan pembahasan}

\section{Tipologi Pesisir Muara Sungai Pemali}

Pesisir Kabupaten Brebes termasuk dalam rangkaian kepesisiran utara Jawa dan berbatasan dengan Kabupaten Tegal di sebelah timur dan Kabupaten Cirebon, Jawa Barat di sebelah barat. Pesisir Brebes pun termasuk pesisir dengan karakteristik pantai yang dangkal karena terletak pada dataran alluvial, yang dipengaruhi oleh aktivitas beberapa sungai baik besar ataupun kecil yang bermuaran di pesisir tersebut (Suyono et al., 2015).
Proses alami yang kebanyakan terjadi di kawasan pesisir seperti di pesisir Brebes diantaranya gelombang, arus, angin, dan pasang, serta proses yang dipengaruhi oleh aktivitas manusia seperti penggunaan lahan, budidaya, dan eksplorasi sumberdaya, sangat berpengaruh pada perubahan garis pantai (Nandi et al, 2015).

Perairan di wilayah pesisir Kabupaten Brebes pada Muara Sungai Pemali memiliki dasar laut yang landai, sedangkan ke arah Timur hingga perbatasan Kota Tegal memiliki dasar laut yang lebih curam. Hasil penelitian 
menunjukkan bahwa kondisi relief daerah penelitian di pesisir kecamatan Brebes dan Kecamatan Wanasari, secara garis besar didominasi oleh relif datar dengan kemiringan lereng ratarata berkisar berkisar 0-2\%. Dapat dilihat Pada Gambar 2.

Kedalaman perairan di pantai Kecamatan Brebes dan Kecamatan Wanasari, memiliki kontur kedalaman yang landai. Hal ini disebabkan oleh gradasi kedalaman pada pantai memiliki interval yang jauh. Menurut (Triatmodjo, 1999), perairan pantai Utara Jawa memiliki kemiringan pantai yang landai. Batimetri mempengaruhi sebaran sedimen yang ada di Pantai Utara Jawa karena kedalaman yang landai dapat menyebabkan penurunan kecepatan gelombang yang disebabkan oleh gesekan gelombang dengan substrat dasar.

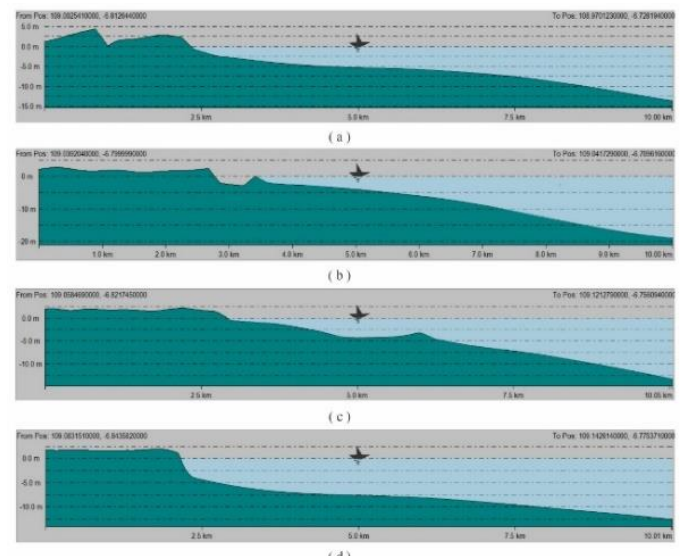

Gambar 2. Relief pantai di wilayah pesisir (a) Desa Sawojajar, (b) Desa Kaliwingi, (c) Desa Randusanga Kulon, dan (d) Desa Randusanga Wetan

Bentuklahan asal proses fluvial di lokasi Penelitian terjadi akibat aliran air dari aktivitas erosi, transportasi, dan sedimentasi. Material sedimentasi berasal dari hasil erosi yang terangkut melalui Sungai Pemali yang kemudian diendapkan yang nantinya akan menghasilkan variasi bentuklahan (Miardini, 2019). Bentuklahan bentukan asal fluvial berhubungan dengan daerah-daerah penimbunan (sedimentasi) seperti lembah-lembah sungai besar dan dataran aluvial. Pada dasarnya bentuklahan ini disebabkan karena proses fluvial akibat proses air yang mengalir baik yang memusat (sungai) maupun aliran permukaan bebas (overlandflow) (Raharjo, 2013).

Bentuklahan asal proses fluvial yang dapat di temui di lokasi penelitian diantaranya (1) Dataran aluvial pada lokasi penelitian cukup luas dengan material pasir dan lumpur, serta didominasi dengan penggunaan lahan pertanian dan pemukiman. Lahan dataran aluvial juga umumnya dapat dimanfaatkan untuk menanam padi dan bawang merah oleh warga yang suplai airnya berasal dari air hujan dan irigasi. Menurut Sampurno, (2001) dataran aluvial sendiri merupakan wilayah yang datar atau hampir datar yang terbentuk oleh endapan yang dibawa air (karena proses fluvial), mayoritas wilayahnya dekat dengan sungai, (2) Dataran banjir di lokasi penelitian merupakan daerah yang sering dan sangat rentan mengalami genangan atau banjir dengan material pasir dan lumpur, serta dinominasi dengan penggunaan lahan tambak dan pemukiman, (3) Tanggul alam pada lokasi penelitian juga terbentuk dekat dengan alur sungai berasal dari proses pengendapan material sungai yang membawa sedimen akibat luapan banjir dengan kuran material sedimen yang kasar mengendap di sekitar palung sungai, dan (4) Rawa Belakang Rawa lokasi penelitian memiliki topografi yang datar hingga cekung dengan beberapa bagiannya selalu tergenang air dan proses sedimentasi masih aktif terletak pada Desa Randusanga wetan dan Randusanga Kulon.

Pada lokasi peneliian Bentuk asal proses fluvial ini tidak bekerja sendiri 
karena terdapat juga proses marin (intrusi melalui muara sungai) sehingga prosesnya disebut dengan proses fluvio-marin sebagai hasil proses Fluvio-Marin. Hal ini dapat terjadi karena pasokan material Sungai Pemali yang diendapkan di pantai jauh lebih besar dibandingkan dengan kecepatan gelombang laut, dan arus yang memindahkan material tersebut. Dengan kata lain pembentukan delta di daerah ini terjadi karena kondisi energi gelombang dan arus yang lemah. sehingga pembentukan delta di daerah penelitian dapat diklasifikasikan sebagai delta yang sangat dipengaruhi oleh sistem fluvial (fluvial-dominated deltas) (Reading H. G, 1986; Hidayat \& Lumbanbatu, 2010). Oleh karena itu, muara yang terbentuk di daerah penelitian sangat terkait dengan kehadiran Sungai Pemali sebagai pemasok sedimentasi.

Bentuklahan asal marin yang dijumpai di lokasi enelitian berupa bentuk lahan sebagai berikut (1) Gisik yang terletak di Pantai Randusanga Wetan, Desa Randusanga Wetan. Satuan bentuklahan gisik berbatasan langsung dengan laut, sehingga sangat dipengaruhi oleh gelombang laut dengan material yang tidak kedap air karena sangat di dominasi pasir; (2) Gosong pantai dimana Satuan bentuklahannya dipengaruhi oleh longshore current yang diakibatkan oleh gelombang pecah yang datang dengan kecepatan tertentu dan membawa sedimen pantai yang akhirnya terendapkan membentuk gosong (Dewadaru et al., 2014).
Bentuklahan gosong pantai pada lokasi penelitian dapat ditemukan di Desa Sawojajar sepanjang lepas pantai dengan penggunaan lahan diperuntukan pada kegiatan pariwisata; (3) Rataan pasut bervegetasi pada penelitian dapat ditemukan di sepanjang garis pantai yang di tumbuhi vegetasi mangrove yang berkembang dengan baik dengan material dasar berupa lumpur; (4) Rataan pasut tidak bervegetasi, pada lokasi penelitian dapat ditemukan di sepanjang pantai yang tanpa adanya penutup vegetasi. Memiliki karakteristik yang jika air surut menampakkan rataan lumpur, dan apabila diperuntukan untuk penggunaan lahan tambak maka rentan mengalami abrasi; dan (5) Daratan aluvial pantai payau pada lokasi penelitian merupakan bentang lahan daratan akibat perkembangan pantai yang telah lanjut dan bergeser ke arah darat yang sekarang telah tertutup oleh material hasil sedimentasi fluvio-marine tersusun oleh material aluvium pasir berlempung. Seperti halnya dataran aluvial pantai payau di daerah lain pada umumnya airtanah di lokasi penelitian memiliki rasa payau dan asin dengan penggunaan lahan pada daratan aluvial pantai payau di dominasi oleh tambak. Peta bentuklahan di lokasi kajian dapat dilihat pada Gambar 3. Pengamatan tipologi dilakukan pada 10 titik pengamatan yang dimana dianggap dapat memberikan gambaran terkait kondisi relief pesisir, materi penyusun utama, proses genesa pembentuknya, hingga kondisi penggunaan lahan yang ada dapat dilihat pada Tabel 1 . 
Kajian Tipologi Pesisir Di Muara Sungai Pemali Kabupaten Brebes Provinsi Jawa Tengah/Eko Ali Saputro, Totok Gunawan, Slamet Suprayogi

Tabel 1. Hasil Pengamatan Tipologi Fisik Pesisir Lokasi Penelitian

\begin{tabular}{|c|c|c|c|c|c|c|c|}
\hline No & Koordinat & Administrasi & Relief & $\begin{array}{c}\text { Materi } \\
\text { penyusun } \\
\text { utama }\end{array}$ & Bentuk Lahan & $\begin{array}{l}\text { Tipologi fisik } \\
\text { pesisir }\end{array}$ & $\begin{array}{c}\text { Penggunaan } \\
\text { Lahan }\end{array}$ \\
\hline 1 & $\begin{array}{l}108^{\circ} 59^{\prime} 14^{\prime \prime} \\
\text { BT - 6॰49'9" } \\
\text { LS }\end{array}$ & $\begin{array}{l}\text { Desa } \\
\text { Sawojajar }\end{array}$ & Datar & $\begin{array}{l}\text { Lumpur dan } \\
\text { pasir }\end{array}$ & $\begin{array}{l}\text { Dataran aluvial } \\
\text { pantai (payau) }\end{array}$ & $\begin{array}{l}\text { Pesisir } \\
\text { pengendapan } \\
\text { laut }\end{array}$ & Tambak \\
\hline 2 & $\begin{array}{l}109^{\circ} 0^{\prime} 10^{\prime \prime} \\
\mathrm{BT}- \\
6^{\circ} 48^{\prime} 34^{\prime \prime} \mathrm{LS}\end{array}$ & $\begin{array}{l}\text { Desa } \\
\text { Sawojajar }\end{array}$ & Datar & $\begin{array}{l}\text { Lumpur dan } \\
\text { Pasir }\end{array}$ & $\begin{array}{l}\text { Dataran aluvial } \\
\text { pantai (payau) }\end{array}$ & $\begin{array}{l}\text { Pesisir } \\
\text { pengendapan } \\
\text { laut }\end{array}$ & Tambak \\
\hline 3 & $\begin{array}{l}108^{\circ} 59^{\prime} 33^{\prime \prime} \\
\text { BT- } 6^{\circ} 47^{\prime} 41^{\prime \prime} \\
\text { LS }\end{array}$ & $\begin{array}{l}\text { Desa } \\
\text { Sawojajar }\end{array}$ & Datar & Pasir hitam & gosong pantai & $\begin{array}{l}\text { Pesisir } \\
\text { pengendapan } \\
\text { laut }\end{array}$ & Pawisata \\
\hline 4 & $\begin{array}{l}109^{\circ} 1^{\prime} 5 " \text { BT } \\
-6^{\circ} 47^{\prime} 45^{\prime \prime} \\
\text { LS }\end{array}$ & $\begin{array}{l}\text { Desa } \\
\text { Kaliwingi }\end{array}$ & Datar & $\begin{array}{l}\text { Lumpur dan } \\
\text { pasir }\end{array}$ & $\begin{array}{l}\text { Rataan pasut } \\
\text { tidak bervegetasi }\end{array}$ & $\begin{array}{l}\text { Pesisir } \\
\text { pengendapan } \\
\text { laut }\end{array}$ & Tambak \\
\hline 5 & $\begin{array}{l}109^{\circ} 1^{\prime} 52^{\prime \prime} \\
\text { BT - } \\
6^{\circ} 47^{\prime} 45^{\prime \prime} \text { LS }\end{array}$ & $\begin{array}{l}\text { Desa } \\
\text { Kaliwingi }\end{array}$ & Datar & $\begin{array}{l}\text { Lumpur dan } \\
\text { pasir }\end{array}$ & $\begin{array}{l}\text { Rataan pasut } \\
\text { tidak bervegetasi } \\
\text { dan Dataran } \\
\text { aluvial pantai } \\
\text { (payau) }\end{array}$ & $\begin{array}{l}\text { Pesisir } \\
\text { pengendapan } \\
\text { laut }\end{array}$ & Tambak \\
\hline 6 & $\begin{array}{l}109^{\circ} 2^{\prime} 14^{\prime \prime} \\
\text { BT - 647'6" } \\
\text { LS }\end{array}$ & $\begin{array}{l}\text { Desa } \\
\text { Kaliwingi }\end{array}$ & Datar & Lumpur & $\begin{array}{l}\text { Rataan pasut } \\
\text { bervegetasi }\end{array}$ & $\begin{array}{l}\text { Pesisir } \\
\text { pengendapan } \\
\text { laut }\end{array}$ & Pariwisata \\
\hline 7 & $\begin{array}{l}109^{\circ} 3^{\prime} 11^{\prime \prime} \\
\text { BT - 6॰47'8" } \\
\text { LS }\end{array}$ & $\begin{array}{l}\text { Desa } \\
\text { Kaliwingi }\end{array}$ & Datar & Lumpur & $\begin{array}{l}\text { Rataan pasut } \\
\text { bervegetasi }\end{array}$ & $\begin{array}{l}\text { Pesisir } \\
\text { pengendapan } \\
\text { laut }\end{array}$ & Tambak \\
\hline 8 & $\begin{array}{l}109^{\circ} 4^{\prime} 0 " \text { BT } \\
-6^{\circ} 47^{\prime} 53^{\prime \prime} \\
\text { LS } \\
\end{array}$ & $\begin{array}{l}\text { Desa R. } \\
\text { Kulon }\end{array}$ & Datar & $\begin{array}{l}\text { Pasir dan } \\
\text { lumpur }\end{array}$ & $\begin{array}{l}\text { Rataan delta dan } \\
\text { dataran banjir }\end{array}$ & $\begin{array}{l}\text { pesisir } \\
\text { pengendapan } \\
\text { darat }\end{array}$ & Tambak \\
\hline 9 & $\begin{array}{l}109^{\circ} 5^{\prime} 7.7^{\prime \prime} \\
\mathrm{BT}- \\
6^{\circ} 49^{\prime} 26^{\prime \prime} \text { LS }\end{array}$ & $\begin{array}{l}\text { Desa R. } \\
\text { Wetan }\end{array}$ & Datar & Pasir Hitam & Gisik & $\begin{array}{l}\text { Pesisir } \\
\text { pengendapan } \\
\text { laut }\end{array}$ & Pariwisata \\
\hline 10 & $\begin{array}{l}109^{\circ} 3^{\prime} 0^{\prime \prime} \text { BT } \\
-6^{\circ} 49^{\prime} 20^{\prime \prime} \\
\text { LS }\end{array}$ & $\begin{array}{l}\text { Desa R. } \\
\text { Kulon }\end{array}$ & Datar & $\begin{array}{l}\text { Lumpr dan } \\
\text { Pasir }\end{array}$ & $\begin{array}{l}\text { Dataran aluvial } \\
\text { pantai (payau) }\end{array}$ & $\begin{array}{l}\text { Pesisir } \\
\text { pengendapan } \\
\text { laut }\end{array}$ & Tambak \\
\hline
\end{tabular}

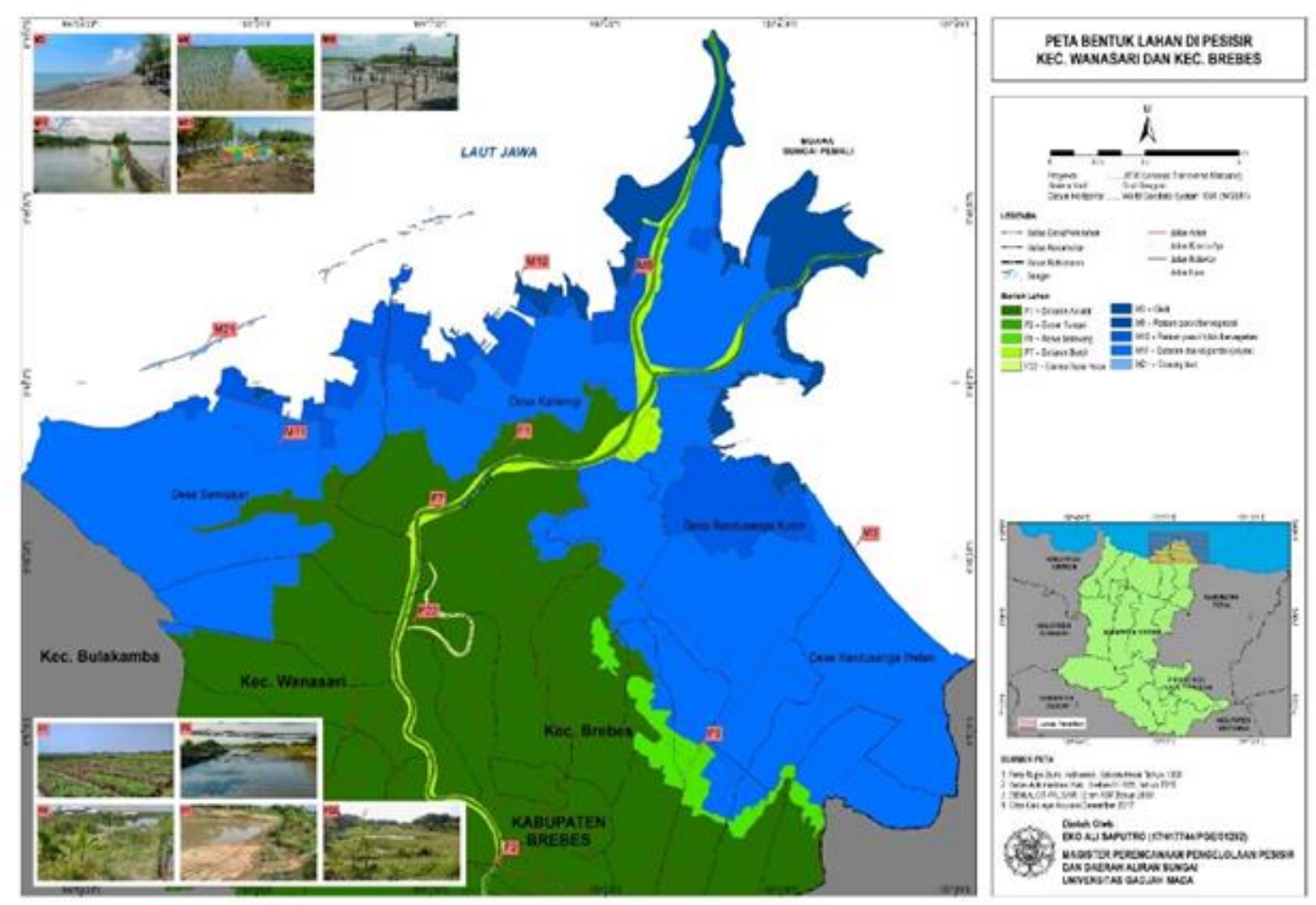

Gambar 3. Peta Bentuk Lahan Lokasi Penelitian. 
Tipologi yang terbentuk di lokasi penelitian yaitu tipologi pesisir pengendapan darat dan tipologi pesisir pengendapan laut. Tipologi pesisir yang pertama merupakan pesisir pengendapan darat (sub aerial deposition coast) dicirikan oleh relief yang datar dengan materi berupa lumpur (lembek), dan proses genesanya berupa proses fluvial (Khakim, 2009). Tipe pesisir pengendapan darat di jumpai di sepanjang Sungai Pemali dengan karakteristik wilayah berupa relief datar, materi penyusun utama berupa materi pasir bercampur lumpur, serta proses genesanya adalah proses fluvial (aliran sungai).

Tipologi Pesisir yang kedua merupakan Pesisir pengendapan laut (marine deposition coast), merupakan pesisir yang dibentuk oleh proses deposisi material atau adanya sedimentasi laut proses yang dominan umumnya adalah pasang-surut, yang termasuk dalam kategori ini adalah pantai berpenghalang, seperti gisik penghalang pulau penghalang teluk dan bura penghalang cuspate foreland, rataan gisik, seperti rataan pasir pantai tanpa lagoon, dan rataan lumpur (mud flat) atau rawa garaman (salt marsh). Berbatuan lunak dan sedimen terkini (recent sediment), mempunyai bentuk pantai yang datar. (Sunarto, 2003).

Secara keseluruhan tipologi fisik pesisir daerah muara Sungai Pemali dan sekitarnya merupakan tipologi pesisir pengendapan laut yang perkembangannya sangat dipengaruhi oleh proses marin dan fluvial. Sedangkan pada daerah yang tipologi pesisirnya banyak dipengaruhi proses marin tipologi pesisirnya merupakan tipologi pengendapan laut. Secara spasial peta tipologi lokasi penelitian tersaji pada Gambar 4.

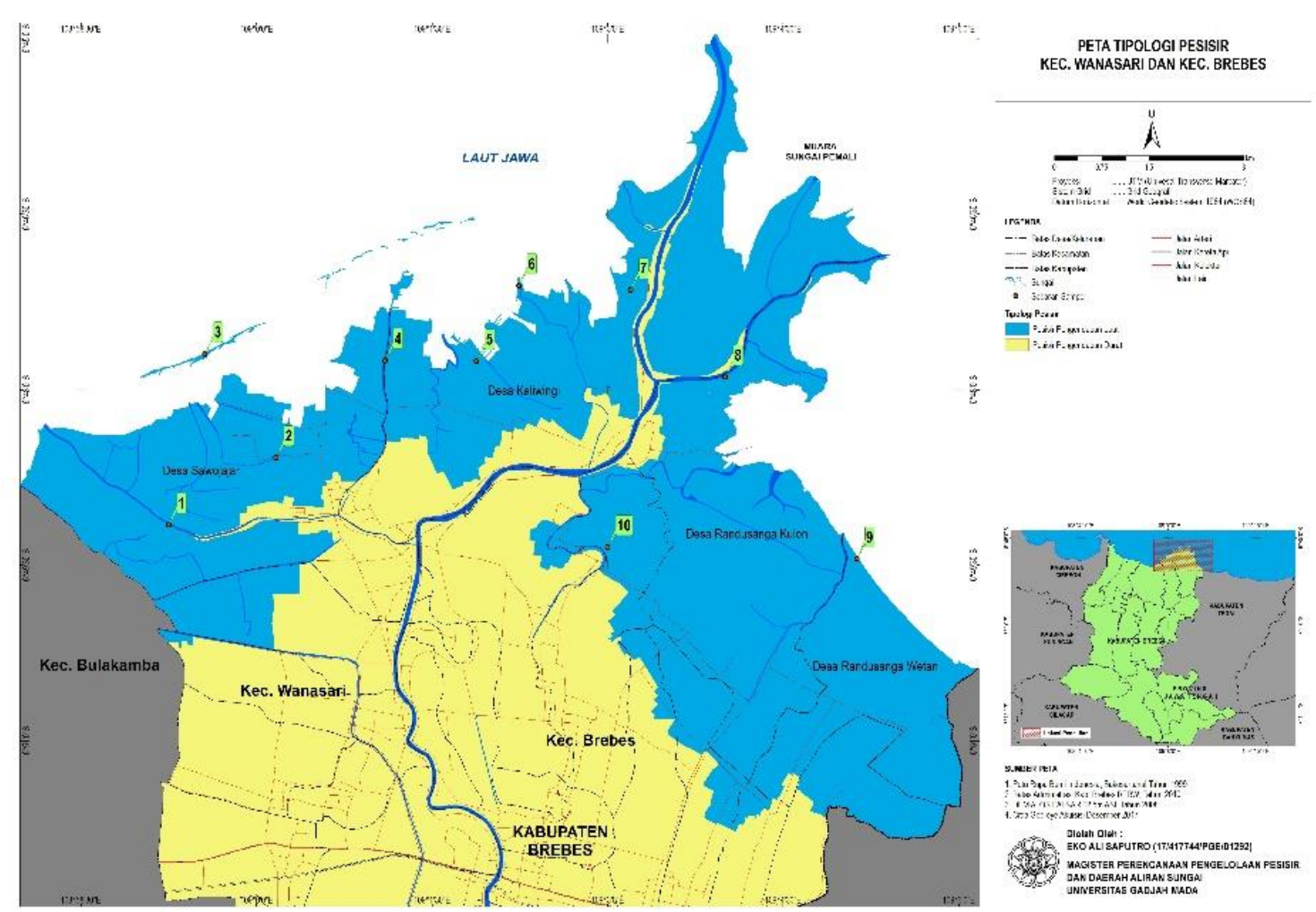

Gambar 4. Peta Tipologi Pesisir Lokasi Penelitian 


\section{Identifikasi Potensi dan permasalahan}

Potensi dan permasalahan yang dapat dirumuskan berdasarkan hasil analisis maupun data skunder dari telaah pustaka hasil penelitian terdahulu. Setelah menganalisis sumber dari permasalahan tersebut, maka akan dirumuskan alternatif pengelolaan yang tepat yang akan disesuaikan dengan rekomendasi program. Maka potensi yang terdapat di lokasi penelitian sebagai berikut.

1) Potensi delta dan rataan lumpur (tanah timbul) sebagai lahan tambak

Aliran Sungai Pemali dan lainnya membawa sedimen dari darat yang cukup besar berpotensi dalam pembentukan delta dan rataan lumpur di muara sungai. Hal ini menyebabkan perkembangan lahan lahan pasang surut (tidal flat) dan rataan lumpur (mud flat) biasa di sebut tanah timbul. Memberikan perluasan pada wilayah administratif yang nantinya dapat dimanfaatkan sebagai peningkatan plasma nutfah dan produksi hasil perikanan.

2) Potensi hutan magrove yang cukup luas

Pada wilayah pesisir Kabupaten Brebes persebaran hutan magrove cukup luas sebab sebagian masyarakat mulai sadar akan pentingnya hutan magrove sebagai perlindungan pantai dan lokasi wisata pantai.

3) Potensi pembentukan gosong pantai

Pembentukan gosong pantai yang beradai di lepas pantai merupakan fenomena menarik untuk dimanfaatkan sebagai lokasi wisata pantai. Menurut (Cahyadi et al., 2017), yang melakukan penelitian serupa pada wilayah karst
Gunungkidul mengemukakan setiap tipologi pesisir memiliki potensi untuk dijadikan tempat wisata, mengingat masing-masing tipologi pantai memiliki karakteristik yang unik yang layak ditawarkan sebagai objek wisata.

Pengembangan wisata bahari sebagai tujuan wisata (destinasi) menjadi salah satu strategi yang bisa dilakukan pemerintah maupun swasta untuk mempromosikan wilayah tersebut sebagai daerah tujuan wisata guna meningkatkan perekonomian dan kesempatan kerja. (Yulisa. dkk. 2016). Dampak positif yang dapat diterima, tidak hanya pada peningkatan pertumbuhan ekonomi dan perluasan kesempatan kerja, tetapi juga akan mendorong masyarakat untuk menjaga dan memelihara keindahan alam yang ditawarkan sebagai objek wisata (Baiquni, 2004). Pengembangan obyek wisata yang ditata dengan baik akan turut berperan dalam meminimalisir kerusakan lingkungan, terutama wilayah pantai dan pesisir yang merupakan wilayah yang rentan terhadap kerusakan lingkungan (Bahar \& Tambaru, 2011)

Wilayah kepesisiran Kabupaten Brebes selain memliki potensi juga memiliki beberapa permasalahan meliputi:

1) Permasalahan Erosi /Abrasi pantai Wilayah Pesisir Kabupaten Brebes mengalami abrasi yang sangat parah, dibuktikan dengan semakin mundurnya garis pantai ke arah darat. Abrasi terjadi bukan hanya disebabkan oleh faktor alam namun juga karena pemanfaatan sumber daya alam yang tidak terkendali sehingga terjadi alih fungsi lahan hutan mangrove menjadi lahan tambak di pesisir Kabupaten Brebes. Hal ini merupakan tantangan terbesar dalam upaya pengendalian 
abrasi pesisir pantai oleh pemerintah dalam membuat kebijakan dan program kerja.

2) Permasalahan konflik kepemilikan lahan (tanah timbul) sebagai lahan tambak

Tanah timbul akibat akresi pantai menjadi salah satu sumber konflik dimana terjadi pemasangan patokpatok sebagai tanda kepemilikan lahan oleh masyarakat setempat. Hal ini tetap terjadi meskipun lahan tersebut masih dalam kondisi terendam perairan pantai. Peran pemerintah dalam mengatur keberadaan tanah timbul tersebut belum sepenuhnya diterima oleh masyarakat di lapangan sehingga keberadaan tanah timbul terus menjadi sumber permasalahan.

3) Banjir Rob yang terjadi di wilayah pesisir

Banjir akibat pasang atau dikenal dengan sebutan banjir rob merupakan jenis banjir yang disebabkan oleh naiknya atau pasangnya air laut sehingga menuju ke daratan sekitarnya. Banjir rob di kawasan Kabupaten Brebes menimpa desa-desa sekitar yang berbatasan langsung dengan laut. Penelitian yang dilakukan oleh (Pahlevi et al., 2018) menemukan bahwa karakteristik banjir rob yang terjadi berdasarkan lama/durasi banjir, waktu banjir, frekuensi dan tinggi banjir, dalam satu tahun terdapat dua mangsa (musim) banjir rob yaitu : mangsa peteruan yang terjadi pada bulan April, Mei dan Juni dan mangsa lanjar yang terjadi pada bulan November dan Desember.

\section{Alternatif Pemacahan Masalah}

Menurut Hidayat (2006) ada beberapa cara untuk melindungi daerah pantai dari abrasi diantaranya mengurangi energi gelombang yang mengenai pantai, mengubah laju angkutan sedimen sejajar pantai, memperkuat tebing pantai, menambah suplai sedimen ke pantai, stabilitas muara sungai, dan melakukan penghijauan daerah pantai dengan pohon bakau.

1) Rehabilitasi Mangrove

Dalam rangka penanggulangan masalah abrasi di pesisir pantai Kabupaten Brebes dapat dilakukan dengan cara upaya rehabilitasi mangrove (green belt) sebagai pelindung alami dan perlindungan pantai dari erosi juga dapat dilakukan dengan menggunakan perlindungan buatan. Bangunan laut dan pantai yang dibangun dapat digunakan untuk melindungi pantai terhadap kerusakan karena serangan gelombang dan arus. Selain itu dapat pula digunakan untuk kepentingan lainnya seperti fasilitas untuk menarik wisatawan khususnya untuk daerah pantai wisata.

Reboisasi dalam upaya rehabilitasi magrove bertujuan untuk mengadakan penanaman pada bekas areal atau kawasan tegakan yang telah hilang atau mengalami kerusakan akibat abrasi di Desa Kaliwingi dan Desa Randusanga Kulon. Pertama, reboisasi mangrove dapat terjadi melalui permudaan secara alami yaitu merupakan proses pertumbuhan yang terjadi secara alami dimana berawal dari buah yang telah masak dan kemudian jatuh ke substrat. Mangrove dapat melakukan pemulihan sendiri namun membutuhkan waktu yang sangat lama dalam periode 15-30 tahun. Dengan syarat tersedianya biji (propagul) atau benih dan kondisi sistem hidrologi pasang surut tidak 
berubah. Kedua, permudaan buatan dilakukan oleh manusia dengan melakukan penanaman secara silvikultur, disesuaikan dengan kehidupan dari jenis mangrove dan syarat zonasi pertumbuhannya. Penanaman jenis bibit mangrove diusahakan sedemikian rupa sehingga mirip dengan kejadian di kawasan alaminya, misalnya masalah zonasi, pasang atau penggenangan, dan salinitas. (Yulistiyanto, 2009; Yesiana et al., 2016)

Peran serta pemerintah dan masyarakat sangat di butuhkan dalam pengelolaan rehabilitasi magrove. Upaya dalam pengelolaan mangrove di wilayah pesisir diperlukan sinkronisasi kegiatan penghijauan di wilayah lain pesisir tanpa memandang ego sektoral, dengan kata lain instansi terkait yang mengelola mangrove hendaknya bersikap arif dan bijaksana agar pengelolaan dapat dilakukan secara maksimal serta memberikan kesejahteraan kepada masyarakat sekitar.

Selain kegiatan penanaman mangrove yang telah dilakukan oleh beberapa instansi pemerintahan, masyarakat sekitar mulai timbul kesadaran untuk menanam kembali mangrove pada areal tambak yang mengalami abrasi. Namun hasilnya belum maksimal karena tanaman selalu habis terbawa ombak. Oleh karena itu, tahap awal yang perlu dilakukan adalah peningkatan perlindungan kawasan mangrove/pantai dari gelombang laut/abrasi dan pengembangan kawasan reboisasi mangrove melalui penahan/pemecah gelombang yang optimal dengan beberapa bangunan struktur pelindung pantai.
2) Membangun struktur pelindung pantai

Perlindungan pantai secara buatan dapat berupa pemecah gelombang (break water), tembok/tanggul laut (sea wall) sejajar sejajar dengan garis pantai, pelindung pantai berupa bangunan (revetment) merupakan salah satu solusi untuk menanggulangi erosi di pantai yang memiliki banyak aktivitas pariwisata. Revetment biasanya dibangun pada garis pantai atau didaratan yang digunakan untuk melindungi pantai langsung dari serangan gelombang, Krib (Gorin) bangunan struktur pelindung pantai yang dibangun menjorok relatif tegak lurus terhadap arah pantai, dan Jetty adalah bangunan tegak lurus pantai yang diletakan di kedua sisi muara sungai yang berfungsi untuk mengurangi pendangkalan alur oleh sedimen pantai. Bangunan-bangunan tersebut dapat dibuat dari kayu, bambu, tumpukan batu maupun beton massif yang harus dibangun kokoh dan stabil untuk menahan gaya hidrodinamika gelombang dan gaya-gaya lain yang timbul. Alat pemecah ombak (APO) sebagai perlindungan bibit mangrove yang hendak ditanam sangatlah penting karena mengurangi resiko kematian pada bibit mangrove. (Priyono, 2010). berada di lokasi Desa Kaliwingi dan Desa Randusanga Kulon.

3) Membuat Peraturan Daerah sepadan pantai dan Sepadan Sungai

Terkait masalah pengelolaan, pemanfaatan dan pelestarian ekosistem pesisir dan perairan laut komponen yang segera di penuhi dalam upaya penanganan erosi dan abrasi pantai di pesisir Kabupaten Brebes adalah dengan kepastian 
hukum (payung hukum), dimana peratuan daerah dapat dijadikan pedoman dalam upaya pengelolaan, pemanfaatan dan pelestarian ekosistem pesisr dan perairan laut, sehingga Peraturan daerah segera dibuat agar dapat menjamin sumberdaya ekosistem pesisir dan perairan laut di sepanjang pantai utara wilayah Kabupaten Brebes, meliputi seluruh wilayah pantai lokasi Penelitian. Sedangkan peraturan kawasan perlindungan setempat sepadan sungai pada sepanjang Sugai Pemali.

4) Inventarisasi Kepemilikan Lahan

Penelitian yang telah dilakukan sebelumnya (Yuniastuti, 2016) di Kepesisiran Demak diketahui bahwa Konflik kepemilikan lahan yang ada di pesisir Demak terjadi karena adanya "tanah timbul" yang tidak jelas kepemilikannya. Hal ini serupa pada lokasi Penelitian Konflik kepemilikan lahan karena adanya tanah timbul. Maka pemerintah melalu Badan Pertanahan Nasional Provinsi perlu melakukann inventarisasi tanah-tanah timbul dan tanah hilang yang terjadi secara alami. Untuk tanah yang hilang apabila sudah ada sertifikatnya agar disesuaikan. Untuk tanah yang akan direklamasi sebelumnya harus diberi tanda-tanda batasnya sehingga bisa diketahui luas tanahnya. Berada pada wilayah yang mengalami akresi yaitu di Desa Sawojajar dan Desa Kaliwingi utamanya pada pembentukan delta muara Sungai Pemali.

5) Penetapan Kawasan Lindung dan Konservasi

Penetapan kawasan lindung/penyangga atau kawasan konservasi disesuaikan dengan potensi dan kekhasan lokal yang mencirikan ekosistemnya, dan diharapkan dapat menjamin plasma nutfah dan keseimbangan ekosistem serta dilengkapi perangkat hukumnya. Seperti Daerah Perlindungan Mangrove (DPM), Kawasan Koservasi Perairan (KKP), Kawasan Konservasi Laut Daerah (KKLD). Penetapan tanah timbul sebagai kawasan lindung dan konservasi sehingga memberikan manfaat bagi masyarakat dan pemerintah, di sepanjang pantai lokasi penelitian yaitu Desa Sawojajar, Desa Kaliwingi, Desa Randusangakulon dan Desa Randusanga Wetan.

6) Pengelolaan lahan di wilayah pesisir pantai

Pengelolaan lahan dalam upaya menanggulangi banjir rob dapat berupa pemantauan alih fungsi lahan dengan ketat, Program konservasi lahan baik secara vegetatif dan mekanik, Penetatan kawasan kawasan tertentu sebagai hutan lindung dan Melakukan pengelolaan tata air secara menyeluruh meliputi drainase kawasan, kolam retensi dan tanggul keliling kawasan. Peta Alternatiff pemecahan masalah pada lokasi penelitian dapat dilihat pada Gambar 5.

Strategi Pengelonan wilayah
pesisir pada lokasi penelitan berdasarkan tipologi Pengendapan darat dan dan tipologi pegendapan laut dapat dikelompokkan menjadi zona sepadan pantai, zona sepadan sungai, zona hutan lindung pantai, zona budidaya tambak, zona budidaya campuran (pertanian irigasi, pemukiman, perdagangan dan perkebunan), dan zona pariwisata secara spasial dapat dilihat pada Gambar 6. 

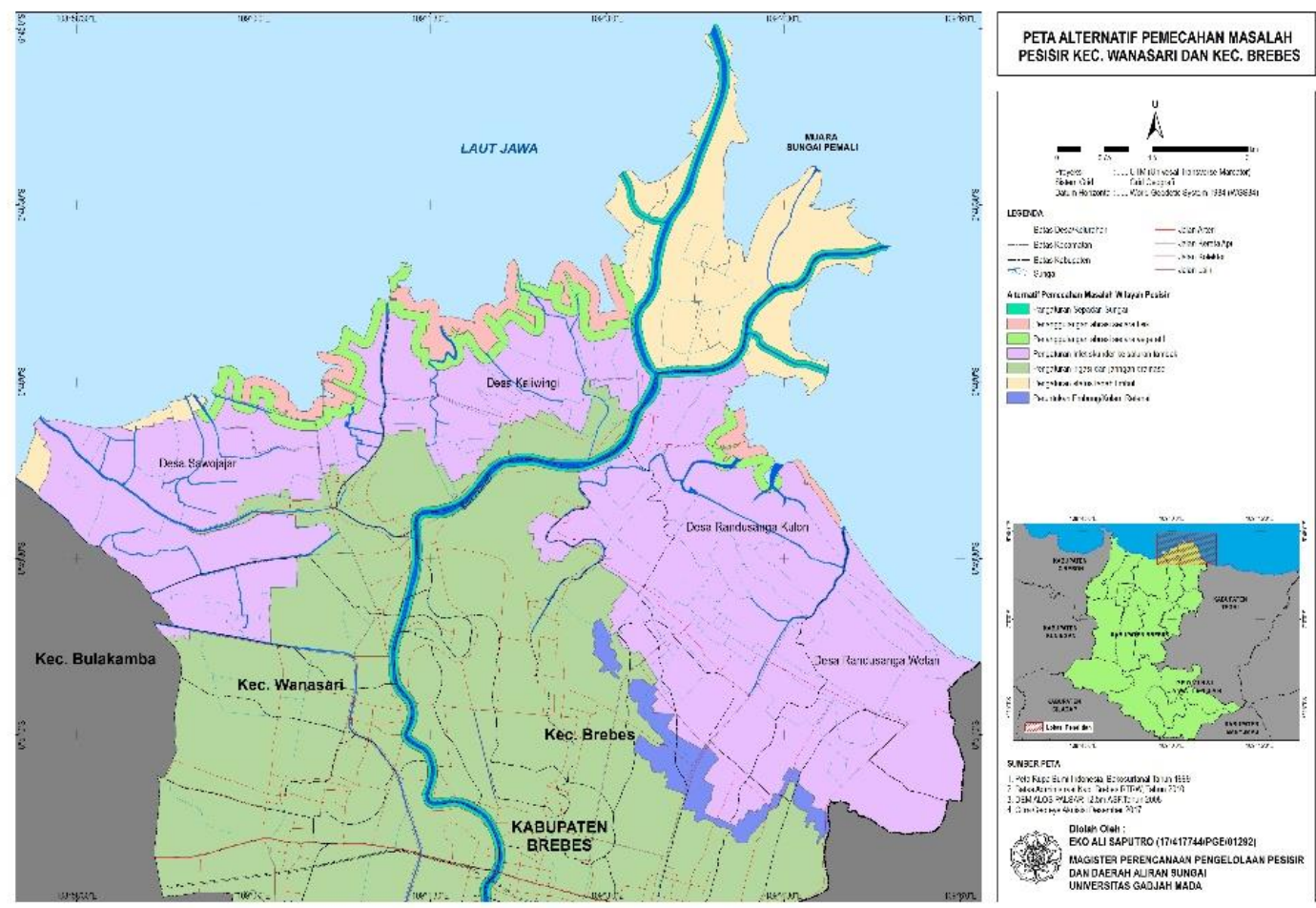

Gambar 5. Peta Pemecahan masalah wilayah kepesisiran Kabupaten Brebes
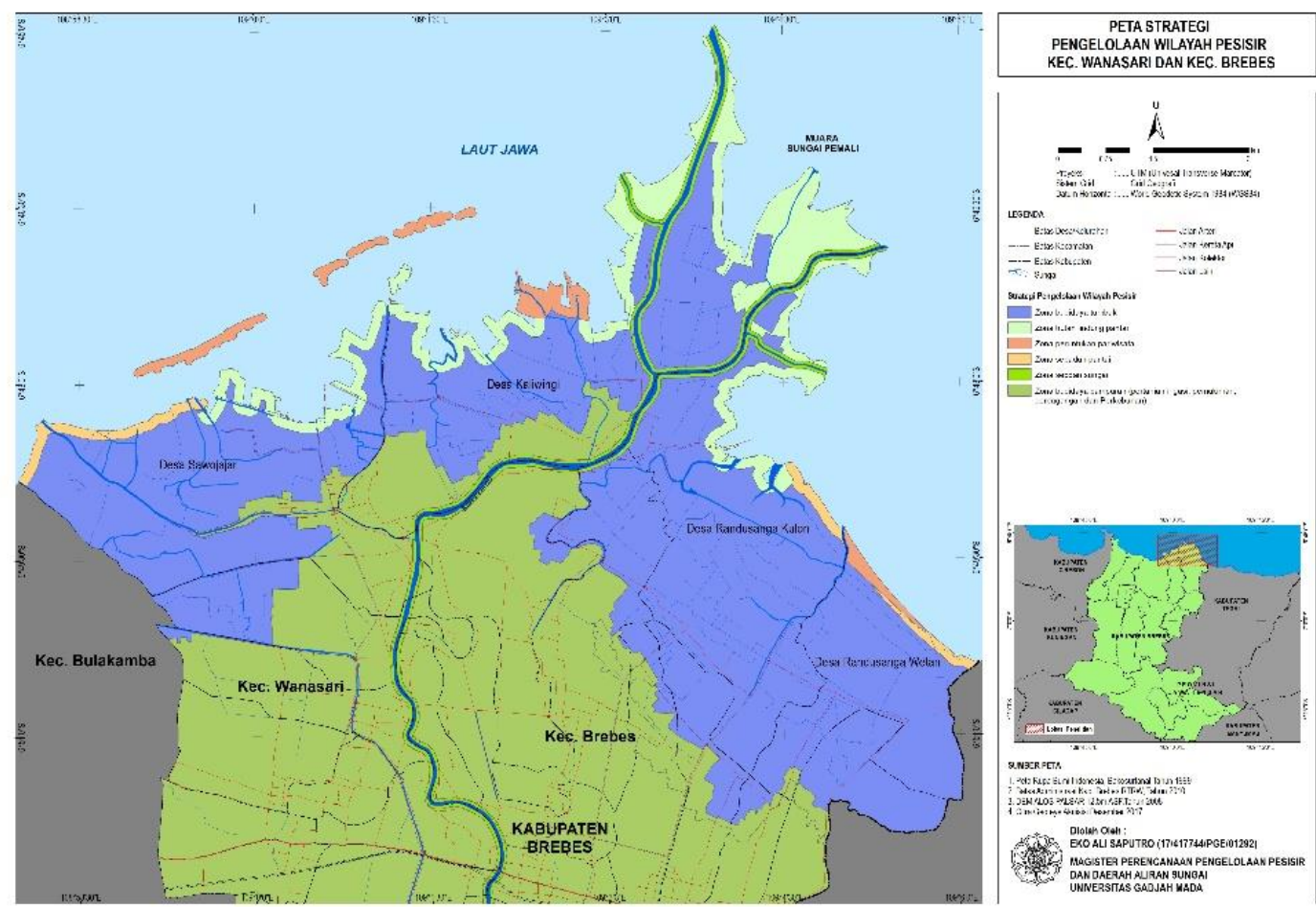

Gamabar 6. Peta Strategi Pengelolaan wilayah kepesisiran Kabupaten Brebes

\section{Penutup}

Berdasarkan hasil analisis tipologi pesisir di Muara pemali terdiri dari tipolo pengendapan darat dan tipologi pengendapan laut. Potensi yang ada di lokasi peelitian terdiri dari Potensi delta dan rataan lumpur (tanah timbul) sebagai lahan tambak, Potensi Hutan magrove yang cukup luas, dan Potensi Pembentukan gosong pantai sebagai 
lokasi pariwisata. Permasalahan di lokasi penelitian terdiri dari Permasalahan Erosi /Abrasi pantai, Permasalahan konflik kepemilikan lahan, dan Banjir Rob. Alternatif pengelolaan di lokasi penelitian terdiri dari melakukan rehabilitasi Mangrove, Membangun struktur pelindung pantai, Membuat peraturan daerah, Melakukan inventarisasi kepemilikan lahan, Penetapan kawasan lindung dan konservasi, serta melakukan pengelolaan lahan secara menyeluruh di wilayah pesisir pantai.

\section{Daftar Pustaka}

Bahar, A., \& Tambaru, R. (2011). Analisis Kesesuaian dan Daya Dukung Kawasan Wisata Bahari Di Kabupaten Polewali Mandar. Jurnal Wisata Bahari Polman- UNRI, 1-18.

Baiquni, M. (2004). Buku Ajar Manajemen Strategis. Program Studi Kajian Pariwisata Sekolah Pascasarjana. Yogyakarta. Universitas Gadjah Mada.

Cahyadi A., Yananto A., \& Hidayat N. H. (2017). Tipologi Pesisir Kawasan Karst Kabupaten Wonogiri. Buletin Geografi Lingkungan, 1(1), 1-12. https://doi.org/10.31227/osf.io/9ay2u

Dahuri, R., Rais, J., Ginting, S. P., \& Sitepu, M. J. (1996). Pengelolaan sumberdaya pesisir dan lautan secara terpadu. Jakarta. PT. Pramadya Paramita.

Dewadaru, D. P., Hariadi, \& Saputro, S. (2014). Kajian Morfologi Pantai di Pantai Slamaran Kabupaten Pekalongan. Journal Of Oceanography. 3(1). 105-123.

Gemilang, W. A., Kusumah, G., Jantama, U., \& Arman, A. (2017). ISOTOP 210 Pb. Jurnal Geologi Kelautan, 15(1), 11-22.

https://doi.org/http://dx.doi.org/10.32 693/jgk.15.1.2017.328

Gemilang, W. A., \& Loka, G. K. (2017). Status Indeks Pencemaran Perairan Kawasan Mangrove Berdasarkan Penilaian Fisika-Kimia Di Pesisir Kecamatan Brebes Jawa Tengah. Jurnal Enviro Scienteae, 12(3), 7990. https://doi.org/http://dx.doi.org/10.20 527/es.v13i2.3919

Gunawan T., Santosa, L. W., Muta'ali, L., \& Santosa, S. H. (2005). Pedoman Survei Cepat Terintegrasi Wilayah Kepesisiran. Badan Penerbit dan Percetakan Fakultas Geografi (BPFG).

Hidayat, N. (2006). Konstruksi bangunan laut dan pantai sebagai alternatif pertindungan daerah pantai. Jurnal SMARTek, 4(1). 10-16.

Hidayat, S., \& Lumbanbatu, U.M. (2010) Analisis bentang alam kuarter daerah cirebon berdasarkan genesanya. Jurnal Geologi dan Sumberdaya Mineral. 20(6). 293-303. https://doi.org/10.33332/jgsm.geologi .v20i6.180

Khakhim, N. (2009). Kajian tipologi fisik pesisir daerah istimewa Yogyakarta untuk mendukung pengembangan Dan pengelolaan wilayah pesisir. (Disertasi). Bogor. Institut Pertanian Bogor.

Marfai, M. A., Cahyadi, A., \& Anggraini, D. F. (2013). Tipologi, dinamika, dan potensi bencana di pesisir kawasan karst kabupaten gunungkidul. Jurnal Forum Geografi, 27(2), 147-158. https://doi.org/10.23917/forgeo.v27i2 .2373

Miardini, A. (2019). Dinamika bentukan lahan fluvial akibat sedimentasi di sungai grindulu, Segmen arjosaripacitan. Jurnal Penelitian Pengelolaan Daerah Aliran Sungai, 3(1), 13-26. https://doi.org/10.20886/jppdas.2019. 3.1.13-26

Nandi, S., Ghosh, M., Kundu, A., Dutta, D., \& Baksi, M. (2015). Shoreline Shifting and Its Prediction Using Remote Sensing and GIS Techniques: A Case Study of Sagar Island, West Bengal India. Journal of Coast Conservation, 20,

61-80. https://doi.org/10.1007/s11852-0150418-4

Ongkosongo, O. S. (1982). The nature of coastline changes in Indonesia. The Indonesia Journal Of Geography, 12, 43.

Pahlevi, M. A., Sarjanti, E., \& Suwarsito. (2018). Karakteristik Banjir Rob dan Penilaian Kerugian Petani Tambak di 
Kabupaten Brebes. Jurnal Sainteks, 15(2), 137-143. https://doi.org/https://doi.org/10.3059 5/sainteks.v15i2.6312

Prijantono, A., Darlan, Y., \& Kusnida, D. (2009). Penelitian Dinamika Pesisir Muara Sungai Comal Dan Sekitarnya, Jawa Tengah, Ditunjang Oleh Penafsiran Data Foto Udara Dan Citra Satelit. Jurnal Geologi Kelautan, 7(1), $1-10$. https://doi.org/http://dx.doi.org/10.32 693/jgk.7.1.2009.165

Priyono, A. (2010). Panduan Praktis Teknik Rehabilitasi Mangrove di Kawasan Pesisir Indonesia. Semarang. KeSEMaT

Raharjo, P. D. (2013). Penggunaan Data Penginderaan Jauh dalam Analisis Bentukan Lahan Asal Proses Fluvial di Wilayah Karangsambung. Jurnal Geografi, 10(2). 167-174. https://doi.org/10.15294/jg.v7i2.85

Ruswandi, Saefuddin, A., Mangkuprawira2, S., Riani, E., \& Kardono, P. (2008). Identifikasi Potensi Bencana Alam dan Upaya Mitigasi yang Paling Sesuai Diterapkan di Pesisir Indramayu dan Ciamis. Jurnal Riset Geologi Dan Pengembangan, 18(2), 1-19.

http://dx.doi.org/10.14203/risetgeota m2008.v18.12

Sampurno. (2001). Pengembangan Kawasan Pantai Kaitannya Dengan Geomorfologi. Seminar-Dampak Timbal Balik antara Pembangunan Kota dan Perumahan di Indonesia dan Lingkungan Global. Pusat Penelitian dan Pengembangan Permukiman. Bandung.

Sunarto. (2003). Geomorfologi Pantai: Dinamika Pantai. Makalah dalam Kegiatan Susur Pantai Karst Gunungkidul pada Raimuna 2003. Yogyakarta. Laboratorium Geomorfologi Terapan Fakultas Geografi Universitas Gadjah Mada.

Suyono., Supriharyono., Hendrarto, B., \& Radjasa, O. K. (2015). Pemetaan Degradasi Ekosistem Mangrove dan Abrasi Pantai Berbasis Geographic Information System di Kabupaten Brebes Jawa Tengah. Jurnal Oceatek, 9(1), 90-102.
Triatmodjo, Bambang. (1999). Teknik Pantai. Yogyakarta : Beta Offset

Yulisa, E., Johan Y., \& Hartono D. (2016). Analisis Kesesuaian dan Daya Dukung Ekowisata Pantai Kategori Rekreasi Pantai Laguna Desa Merpas Kabupaten Kaur. Jurnal Enggano, 1(1), 97-111. https://doi.org/10.31186/jenggano.1. 1.97-111

Yulistiyanto, B. (2009). Mangrove dengan alat pemecah ombak (APO) sebagai perlindungan garis pantai. Proseding pada Seminar Nasional 2009. "Manajemen Sumberdaya Air Partisipatif Guna Mengantisipasi Dampak Perubahan Iklim Global". (Vol. 8).

Yesiana, R.,Hidayati, I. Y., \& Wicaksono, G. (2016). Penguatan Ekosistem Pesisir: Monitoring dan Pembelajaran Pembangunan Alat Pemecah Ombak (APO) di Kota Semarang. Jurnal Wilayah dan Lingkungan, 4(3), 199212. https://doi.org/10.14710/jwl.4.3.199212

Yuniastuti, E. (2016). Identifikasi tipologi dan dinamika, potensi dan Permasalahan, dan strategi pengelolaan wilayah Kepesisiran di wilayah kepesisiran demak. Jurnal Geografi, $\quad 8(1)$, 31-45. https://doi.org/10.24114/ig.v8i1.5314 